\title{
Comparison of Competitiveness for Crop Estate Commodities in ASEAN and European Markets: Constant Market Share Approach
}

\author{
Lya Aklimawati ${ }^{1 *}$ \\ ${ }^{1)}$ Indonesian Coffee and Cocoa Research Institute, J1. PB. Sudirman 90, Jember, Indonesia \\ ${ }^{*}$ Corresponding author: lya.akli@gmail.com \\ Received: 13 November 2015 / Accepted: 27 November 2015
}

\begin{abstract}
Market transition to free trade agreement encourages Indonesia to improve foreign trade performance through stabilization of market position in the international market. The aims of this research were to analyze the competitiveness of coffee, cocoa, palm oil and rubber products in the international market, and to analyze Indonesia's export dynamic in ASEAN and European markets. This research was conducted by analyzing secondary data particularly export data from 2010 to 2015. Revealed Comparative Advantage (RCA) and Constant Market Share (CMS) approaches were used to analyze export competitiveness of Indonesian products in the world market. The results showed that Indonesian agricultural products (coffee, cocoa, palm oil and rubber) had a comparative advantage over the average rate of world (RCA > 1), except natural rubber products. Meanwhile, CMS analysis indicated that dynamic of Indonesian export was more affected by export growth and product composition effects, than that of market distribution and competitiveness effects. It revealed that Indonesia responded less to market demand in terms of quality, import growth of export destination countries and market intelligence related to competitor market positioning.
\end{abstract}

Keywords: RCA, CMS, coffee, cocoa, rubber, palm oil

\section{INTRODUCTION}

Development of today free trade brings its own implication for the economy of certain country. Relationship in cooperation among countries will be widely opened to fasten the flow of goods and services for the countries involved in the trade (Oktaviani et al., 2008). The freedom of trade creates the opportunity to open up the new market for producer countries which have important commodity in world trade. This potential can be utilized especially for Indonesia in expanding their market reach. Concerning that Indonesia has various commodities which are traded in international market, and as agricultural country, Indonesia has productive sources especially in plantation sector. This sector has given real contribution on the growth of national economy as the contributor of foreign exchange of the country.

Plantation commodities that takes role in sustaining the national economy are especially coffee, cocoa, palm oil and rubber, which is based on the performance of export in 2013 on each comodity that reaches US\$ 1.17 billion for coffee, US\$ 1.15 billion for cocoa, US\$1.84 billion for palm oil and US\$ 6.90 billion for rubber (Ditjenbun, 2014). The commodities have placed Indonesia as producer that has quite wide export segment in international market (Nuryanti, 2008; Arifin 2013). By increasing the volume of trade, it 
is expected that it can improve the structure of national community until it gets to better level.

The trade of plantation commodities in Indonesia depends on sthe global economy fluctuation and the condition of economy of export destination country. Therefore, the slowing condition of global economy influence the characteristics of trade among countries which are marked by the decreasing of consumption level of goods and services by importing countries (Dermoredjo \& Setiyanto, 2008; Oktaviani et al., 2008; Simorangkir \& Adamanti, 2010). This phenomenon is one of the market risks in international trade. Beside the opportunity in expanding the market, there is also a challenge in form of tight competition in reaching new markets. According to the growth of export on plantation commodities, the growth of export in Indonesia, either the primary plantation commodities or its derivative products tended to be slower than the growth of world export as the consequence of weak competitiveness, product diversification and market distribution. The primary commodity of plantation in Indonesia tended to have comparative excellence than the competitor countries. However, Indonesia is still lose in competition with the international market especially the derivative products like the primary products of plantation (Hadi \& Mardianto, 2004; Daryanto, 2009).

Considering competitiveness, the competitiveness of Indonesia coffee products was still lost from the comparison with other countries like Brazil, Colombia, Honduras, Peru and Vietnam (Bustami \& Hidayat, 2013; Dradjat et al., 2007). The competitiveness constraint does not prevent Indonesia from utilizing the opportunity of niche market in trading special coffee. The special coffee will be appreaciated with premium price because it has high historical price, high quality and unique taste based on certain geographical area (Dradjat et al., 2007). Cocoa products in Indonesia also do not have the excellence of competitivenss and market distribution towards the cocoa products of Ghana, Ivory Coast, and Malaysia (Dermoredjo \& Setiyanto, 2008; Hasibuan et al., 2012). Indonesia has no strong competitiveness for palm oil products and its derivative products comparing to Malaysia. It is known that CPO product of Indonesia in 2011 reached 24 million tons, while the production of $\mathrm{CPO}$ in Malaysia was still less than 20 million tons. This places Indonesia as the biggest producer in the world. Even though the segment of Indonesian market for the products of palm oil and the derivative products in the world market is higher than Malaysisa, Malaysia has the tendency to have the excellence in using the market opportunity and market distribution in main importing countries (Arip et al., 2013; Arifin, 2013; Rifin, 2010). It goes the same as rubber products. Thailand has the tendency to have the competitiveness excellence and market disribution comparing to the rubber products from Indonesia. Therefore most of rubber products in Indonesia is exported in form of primary products like latex and slab (Arifin, 2013; Hadi \& Mardianto, 2004).

Trade performance of plantation commodities either in the national market or international one, experiences more complex change as the consequence of the enforcement of trade freedom. The consequence is that there is the change of offer and request towards the commodity caused by price fluctuation, implementation of regional trade cooperation, and other supporting factors relating to investment, health, food security and environment preservation. At the same time, Indonesia also faces some constraints related to product trade of agricultural export which include low plantation productivity in farmer level, pressure of environmental preservation issue (sustainability), low product 
quality, low investment in agricultural sector, insufficient infrastructure, implementation of cultivation techniques (good agricultural practices) characterized as traditional and limited access towards government policy (Arifin, 2013). In terms of defending and expanding the market, products of Indonesian plantation are demanded to have higher competitiveness than the same product from the competitor country. In connection with it, this study aimed to analyze the competitiveness of coffee, cocoa, plam oil and rubber commodities in international market, and to analyze market dynamics of export market from Indonesia to ASEAN and European markets.

\section{MATERIALS AND METHODS}

\section{Framework}

The consequence of free trade is the openness in trade process among countries so three is an opportunity to step on new market. However, the easiness of trade access through the scheme of free trade also brings challenge to the country of which the commodity belongs to especially Indonesia in defending market position in international market. By entering the era of free trade, Indonesia is demanded to produce a product that has strong competitiveness in competing with the same product in global market. The strong competitivenes will lead to the advantage of the increasing of export and the growth of economy. At the same time, the weak competitiveness will cause a negative impact on the growth of Indonesian economy as the effect of overflow of import inside the country (Saktyanu cit. Permatasari \& Rustariyuni, 2015).

In defending the existence of market in the era of free trade, as stated by Hadi \& Mardianto (2004), Indonesia should pay attention to three important components which includes the composition of products, market distribution and competitiveness. Therefore, utilization of commodity potential which has competitive excellence should be optimized. In plantation sector, the export commodity with quite wide market sector is coffee, cocoa, palm oil, and rubber. Those four commodities have brought Indonesia to be considered country in the world market. Even though the export potential from those four commodities is quite large but there is no quarantee of the market certainty yet. This is caused by the market position that is buyer market or it can be said that the market follows the consumer request (Hakim, 2003). This condition can be a challenge for Indonesia to increase additional value of the products so it is able to improve the offering position in the global market. This research studied the competitiveness of Indonesian products especially coffee, cocoa, palm oil, and rubber, as well as the dynamics of commidity trade in some markets of export goal.

\section{Data and Research Scope}

In this study, the research data were secondary data from International Trade Center (ITC) and United Nations Commodity Trade Statistics (UN COMTRADE). The secondary data were used as materials of Revealed Comparative Advantage (RCA) and Constants Market Share (CMS) analysis. The data used for both analysis are export values of coffee, cocoa, palm oil, and rubber commodity during 2001-2015.

The scope of the research included two markets which become the export goals of Indonesia; they are ASEAN and European markets. Those two markets were selected with the consideration that the commodity of Indonesian plantation was quite a lot to be traded in the markets (Dermoredjo \& Setiyanto, 2008). The commodities analyzed in this research were coffee, cocoa, palm 
oil, and rubber with Harmonized System (HS) Code 1996 4-digit and 6-digit. In international trade, Harmonized Commodity Description and Coding System or Harmonized System is an international standard for naming and numbering system used to classify the trade product as well as the derivative product based on the category issued by World Customs Organization (WCO). In the naming and numbering system on Harmonized System, the first four digits are called WCO post which means that all codes of HS in the world have the same product. The next two digits (fifth and sixth digits) are called as WCO sub-post. The commodity with HS 1996 four digit code includes (0901), cocoa (1801, 1802, 1803, 1804, 1805, 1806), rubber (4001), and palm oil $(1511,1513)$. The commodity with HS 1996 6-digit code includes coffee, (090111), cocoa (180100), rubber (400110), palm oil/CPO (151110), and palm core oil/CPKO (151321). The majority of HS commodity is the export product of Indonesia which has been traded in ASEAN and European market. The period of research in RCA analysis involves 15 years from 2001-2015. The analysis of CMS is observed for 5 years (2011-2015) for ASEAN market and 6 years (2010-2015) for European market. This is due to the limitation of data of Indonesian trade to ASEAN and European market. In accordance with that, the interpretation and conclusion drawing of the analysis result needs circumspection and the support from previous studies.

\section{Analysis Method}

The approach used to measure the comparative excellence of a country in international trade is Revealed Comparative Advantage (RCA). The analysis is formulated as such:

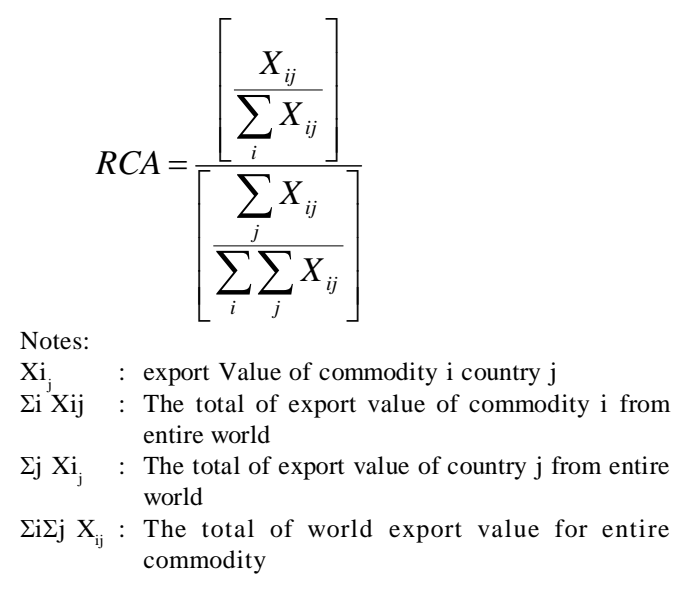

The interpretation from RCA value which is RCA value is the same or more than $1(\mathrm{RCA} \geq 1)$ indicating that the country has comparative excellence of product above the world average because it has segment market above the world average. In reverse, the RCA value is less than 1 $(\mathrm{RCA}<1)$ indicating that the country has the comparative excellence product under the world average.

At the same time, the dynamics of Indonesian trade to ASEAN and European markets will be analyzed using Constants Market Share (CMS) apporach. Suprihatini (2005) states that CMS analysis can be used to discover the diversity of export of certain country relatively to the competitor. Besides, the analysis is also useful to study the ability of exporting country in managing the perfomance of export to the entire targeting markets in certain period of time through a set of statistical indicators. The basic of understanding for the use of CMS analysis is that the development rate of a country's export can be smaller, or equal or larger than export growth rate of world average (Oktaviani et al., 2008). The assumption of this analysis base is that the segment of export market of certain country in 
the world market does not change from time to time so the change of competitiveness on a time that is not between two periods of time will be ignored. The equa- tion in CMS analysis referred to formulation used by Tyers et al. cit. Suprihatini (2005) by using 4 terminologies, that are:

$\frac{E_{(t)^{* *}}-E_{(t-1)^{* *}}}{E_{(t-1)^{* *}}}=g+\frac{\sum_{i}\left(g_{i}-g\right) E_{(t-1)^{* *}}}{E_{(t-1)^{* * *}}}+\frac{\sum_{i} \sum_{j}\left(g_{i j}-g_{i}\right) E_{(t-1)_{i j}}}{E_{(t-1)^{* * *}}}+\frac{\sum_{i} \sum_{j}\left(E_{(t)_{i j}}-E_{(t-1)_{i j}}-g_{i j} E_{(t-1)_{i j}}\right)}{E_{(t-1)^{* * *}}}$

Notes:

$\frac{E_{(t)^{*}}-E_{(t-1)^{* *}}}{E_{(t-1)^{*}}}=g$

$\frac{\sum_{i}\left(g_{i}-g\right) E_{(t-1) i^{* *}}}{E_{(t-1)^{* * *}}}$

Effect of Product Composition

$\sum_{i} \sum_{j}\left(g_{i j}-g_{i}\right) E_{(t-1)_{i j}}$ $E_{(t-1)^{* * *}}$

$\frac{\sum_{i} \sum_{j}\left(E_{(t)_{i j}}-E_{(t-1)_{i j}}-g_{i j} E_{(t-1)_{i j}}\right)}{E_{(t-1) * *}}$

where,

$$
\begin{aligned}
& g=\frac{W_{(t) * *}-W_{(t-1) * *}}{W_{(t-1) * *}} \\
& g_{i}=\frac{W_{(t) i}-W_{(t-1) i}}{W_{(t-1) i}} \\
& g_{i j}=\frac{W_{(t) i j}-W_{(t-1) i j}}{W_{(t-1) i j}}
\end{aligned}
$$


Notes:

$\mathrm{E}_{(\mathrm{t})^{* *}}:$ the total of value of Indonesian export for the entire product in year $(\mathrm{t})$

$\mathrm{E}_{(\mathrm{t}-1)^{* * *}}:$ the total of value of Indonesian export for the entire product in year $(\mathrm{t}-1)$

$\mathrm{E}_{(\mathrm{t}) \mathrm{i}}:$ the total of value of Indonesia for coffee/cocoa/rubber/palm oil product in year $(\mathrm{t})$

$E_{(t) i j}:$ the total of value of Indonesia for coffee/cocoa/rubber/palm oil product to ASEAN/European market in year $(\mathrm{t})$

$\mathrm{W}_{(\mathrm{t})^{* *}}$ : the total of value of world export for the entire product in year $(\mathrm{t}-1)$

$\mathrm{W}_{(\mathrm{t}-1))^{* * *}}:$ the total of value of world export for the entire product in year (t-1)

$\mathrm{W}_{(\mathrm{t}) \mathrm{i}}$ : the total of value of world for coffee/ cocoa/rubber/palmoil product in year $(\mathrm{t})$

$\mathrm{W}_{(\mathrm{t}) \mathrm{ij}}$ : the total of value of world for coffee/ cocoa/rubber/palm oil product to ASEAN/European market in year $(\mathrm{t})$

\section{RESULTS AND FINDING}

\section{Revealed Comparative Advantage}

In this study, number of RCA products of plantation commodity with HS 6-digits code (coffee beans, cocoa beaans, crude palm oil, and crude palm kernel oil) which were more than 1 in the period of 2001 to 2015 except for the natural rubber product. The value of RCA which were more than 1 means that the commodity of plantation excellence in form of primary product has the comparative excellence in the world market because the commodity segment in the world export total. The value of RCA of a larger commodity shows that the commodity has the stronger comparative excellence. In the period of 2001 to 2015 , the RCA value of plantation products with HS 6-digits code showed fluctuative movement with decreasing tendency. The RCA value which moved stable enough from time to time was shown by the coffee beans product while for the other plantation products, it is relatively fluctuative.

Based on these five plantation products, the average of highest RCA value was in the period of 2001 to 2015 was reached by the crude palm kernel oil product (73.0608) while the lowest RCA value was natural rubber product (0.8500). The detail of RCA value of each commodity can be seen in Table 1 .

Based on Table 1, it can be seen that primary product in form of palm oil had the higher comparative excellence than the other plantation commodities. However, the RCA value of both primary products from the palm oil tended to decrease. The decreasing of RCA value that was quite drastic happened on the cocoa beans product in the period of 2011-2015. The decreasing of RCA value was expected to be in effect of tariffs progressively towards the product of plantation export especially cocoa beans and palm oil. The determination of tariffs was out in force since 2010 through the Minister of Finance Regulation No. 67/PMK.011/2010 on Requirement Export Goods Subject to Duty and Tariff. This regulation was revised with the latest changes in Finance Minister Regulation No. 75/PMK.011/2012. The implementation of this policy was signaled to decrease the export volume of cocoa beans and palm oil to support the downstream industry inside the country. Besides, the product of cocoa beans in Indonesia has lower quality and price than other exporting countries so Indonesian product is only used as the mixing material by the industrial country of cocoa processor (Hasibuan et al., 2012). Different from the coffee bean products, the RCA value of the product tended to increase even in relatively small amount. Even though the RCA value was fluctuative, it indicated that 
Table 1. Comparative advantage of coffee bean, cocoa bean, natural rubber, palm oil and palm kernel oil by using RCA method in 2001-2015

\begin{tabular}{|c|c|c|c|c|c|}
\hline \multirow{2}{*}{ Year } & \multirow[b]{2}{*}{ Coffee bean } & \multicolumn{4}{|c|}{ RCA value (6-digits HS Code) } \\
\hline & & Cocoa bean & Natural rubber & Crude palm oil & Crude palm kernel oil \\
\hline 2001 & 3,902 & 14,296 & 1,642 & 45,921 & 73,845 \\
\hline 2002 & 5,154 & 15,878 & 1,203 & 65,320 & 85,386 \\
\hline 2003 & 5,596 & 13,640 & 1,545 & 67,312 & 86,617 \\
\hline 2004 & 5,311 & 12,039 & 1,412 & 75,183 & 86,374 \\
\hline 2005 & 6,721 & 13,480 & 0,503 & 72,917 & 84,702 \\
\hline 2006 & 6,460 & 16,725 & 0,803 & 67,684 & 90,743 \\
\hline 2007 & 5,908 & 15,762 & 0,585 & 74,430 & 87,932 \\
\hline 2008 & 7,244 & 17,017 & 0,745 & 74,883 & 85,480 \\
\hline 2009 & 6,296 & 13,851 & 0,628 & 71,561 & 82,968 \\
\hline 2010 & 4,489 & 13,686 & 1,059 & 65,961 & 75,504 \\
\hline 2011 & 3,530 & 5,690 & 0,615 & 52,862 & 64,038 \\
\hline 2012 & 5,204 & 0,366 & 0,566 & 49,020 & 54,044 \\
\hline 2013 & 6,681 & 5,695 & 0,382 & 51,161 & 44,276 \\
\hline 2014 & 5,273 & 2,141 & 0,463 & 46,744 & 41,792 \\
\hline 2015 & 6,534 & 1,247 & 0,601 & 52,795 & 52,210 \\
\hline Average & 5,6202 & 10,7676 & 0,8500 & 62,2503 & 73,0608 \\
\hline
\end{tabular}

Source: Processed secondary data

the products of coffee beans, cocoa beans, crude palm oil, and crude palm kernel oil had the strength on the production efficiency side so the product with same quality will have cheaper price than the other producer country (Nurlaitfah, 2011). Therefore, those four primary products had the chance to face the market competition with the same product which came from other producing countries.

Particularly for the product of natural rubber, RCA value was still under 1 (one) which indicated that the performance of natural rubber export in Indonesia had not paid attention to the principle of production efficiency yet. In other words, Indonesia had not optimized yet in utilizing the availability of land, use of workers and use of other production input. The other factors which caused the competitiveness of natural rubber in Indonesia still low were low productivity and market segment of natural rubber in Indonesia than the other competitor countries like Thailand and Malaysia (Radityo et al., 2014). The low competitiveness of natural rubber in Indonesia in the world market needs to get special attention to increase the production efficiency in the management in order to result in more competitive products than the competitor countries.

For the category of plantation products with HS 4-digit code (all kinds of products), it showed that the highest RCA value in 2001 to 2015 period of time was palm oil while the lowest value was cocoa. Even though the RCA value was fluctuative from year to year, it tended to move up from 2012. Beside that, RCA value of plantation commodity for the category of export product with HS 4-digit code showed the value above 1 (one) so the plantation product from Indonesia had the comparative excellence in international market. However, the RCA value of coffee product and cocoa product was relatively smaller than rubber and palm oil. Therefore, utilization of productive resources need to be optimized, such as lands, workers and other production factors to increase the productivity and the performance of export. The RCA value of plantation product with HS 4-digit score can be seen in Table 2. 
Table 2. Comparative advantage on coffee, cocoa, rubber, palm oil products by using RCA method in 2001-2015

\begin{tabular}{|c|c|c|c|c|}
\hline \multirow{2}{*}{ Year } & \multicolumn{4}{|c|}{ RCA value (4-digits HS Code) } \\
\hline & Coffee & Cocoa & Rubber & Palm oil \\
\hline 2001 & 3,055 & 3,552 & 25,417 & 27,743 \\
\hline 2002 & 3,825 & 5,200 & 26,474 & 36,748 \\
\hline 2003 & 4,191 & 3,503 & 27,751 & 35,347 \\
\hline 2004 & 4,071 & 3,467 & 31,695 & 44,550 \\
\hline 2005 & 4,920 & 3,758 & 31,345 & 47,253 \\
\hline 2006 & 4,721 & 4,379 & 33,871 & 47,560 \\
\hline 2007 & 4,338 & 0,442 & 35,919 & 49,988 \\
\hline 2008 & 5,273 & 4,464 & 35,443 & 47,877 \\
\hline 2009 & 4,392 & 4,373 & 28,810 & 47,329 \\
\hline 2010 & 3,211 & 4,111 & 28,262 & 42,792 \\
\hline 2011 & 2,559 & 2,750 & 22,773 & 37,435 \\
\hline 2012 & 3,650 & 1,556 & 20,906 & 44,191 \\
\hline 2013 & 4,266 & 2,716 & 27,470 & 47,703 \\
\hline 2014 & 3,464 & 2,685 & 30,099 & 52,638 \\
\hline 2015 & 4,260 & 2,386 & 30,412 & 55,789 \\
\hline Average & 4,013 & 3,290 & 29,110 & 44,329 \\
\hline
\end{tabular}

Source: Processed secondary data.

\section{Constant Market Share}

\section{Standard Development}

In general, elaboration of the analysis result of the export development as seen in Table 3 showed that coffee beans, natural rubber and palm oil from Indonesia had higher export development than the standard development. The high export development in Indonesia can utilize the standard development which indicated that Indonesia can utilize the market opportunity and the advantage of trade side by the development of world trade. Utilization of world trade development can be done in form on increasing export performance to fulfill demand from the world market, while for the cocoa beans and palm kernel oil, lower export development than the standard development. This is caused by the lower competitiveness of the product than the other producing countries which produce the same products. The low export development from both primary products can be handled by increasing the export of dairy products. This is shown through the performance of cocoa export and its derivative products as well as the palm oil and its derivative products (HS 40 digit code) which showed higher development than the standard one. The increasing of dairy product export will also show the additional value of the product which gets higher. Moreover, the increasing of produxt export will be done by promotion, product differentiation, and market investigation to discover the market needs and consumer desire (Oktaviani et al., 2008; Hadi \& Mardianto, 2004).

During the period of 2001 to 2015 , development of total export of the entire Indonesian product to the world which was higher than the standard development (export development of entire world product) only happened in the period of 2004 to 2012. For the product category with HS 6-digit code, the export development of coffee seeds Indonesia was higher than the standard development happening in the period of 2001 to 2009 and the period of 2013 to 2015 . For the cocoa bean products, the Indonesian export development was higher than the standard development which went on during the period of 2004 to 2006 and the period of 2013 to 2015 . For the natural rubber product, 
Table 3. Standard growth and export growth of Indonesia total products, coffee, cocoa, rubber, and palm oil to world market in 2001-2015

\begin{tabular}{|c|c|c|c|c|c|c|}
\hline \multirow{2}{*}{ Comodity } & \multirow{2}{*}{ Export growth } & \multicolumn{5}{|c|}{ Year } \\
\hline & & $2001-2003$ & $2004-2006$ & $2007-2009$ & $2010-2012$ & $2013-2015$ \\
\hline \multirow[t]{2}{*}{ Total product } & Standard growth & 0,07093 & 0,17045 & 0,02767 & 0,14649 & $-0,03547$ \\
\hline & Indonesian export growth & 0,02772 & 0,18192 & 0,06105 & 0,19260 & $-0,07378$ \\
\hline \multicolumn{7}{|c|}{ HS 6-digits code } \\
\hline \multirow{2}{*}{ Coffee beans } & Standard growth & 0,02940 & 0,25132 & 0,10187 & 0,21555 & $-0,03751$ \\
\hline & Indonesian export growth & 0,11494 & 0,35387 & 0,15937 & 0,15471 & $-0,00816$ \\
\hline \multirow{2}{*}{ Cocoa beans } & Standard growth & 0,25895 & 0,06084 & 0,24390 & 0,07174 & 0,01031 \\
\hline & Indonesian export growth & 0,23321 & 0,16318 & 0,21697 & $-0,44212$ & 3,20588 \\
\hline \multirow{2}{*}{ Natural rubber } & Standard growth & 0,24250 & 0,32526 & $-0,01720$ & 0,24331 & $-0,17927$ \\
\hline & Indonesian export growth & 0,22071 & 0,39500 & $-0,02988$ & 0,50614 & $-0,17902$ \\
\hline \multirow[t]{2}{*}{ Crude palm oil } & Standard growth & 0,28433 & 0,22334 & 0,41505 & 0,17984 & $-0,11325$ \\
\hline & Indonesian export growth & 0,46189 & 0,23806 & 0,49977 & 0,08320 & $-0,12208$ \\
\hline Crude palm & Standard growth & 0,23534 & 0,37016 & 0,28386 & 0,10719 & $-0,00105$ \\
\hline kernel oil & Indonesian export growth & 0,27391 & 0,38725 & 0,27735 & 0,03659 & $-0,00944$ \\
\hline \multicolumn{7}{|c|}{ HS 4-digits code } \\
\hline \multirow{2}{*}{ Coffee } & Standard growth & 0,04376 & 0,25242 & 0,11354 & 0,20900 & $-0,01958$ \\
\hline & Indonesian export growth & 0,11503 & 0,33894 & 0,15680 & 0,15554 & $-0,00760$ \\
\hline \multirow[t]{2}{*}{ Cocoa } & Standard growth & 0,15305 & 0,08656 & 0,14028 & 0,08881 & 0,02732 \\
\hline & Indonesian export growth & 0,17688 & 0,18590 & 3,54525 & $-0,16435$ & 0,18048 \\
\hline \multirow{2}{*}{ Rubber } & Standard growth & 0,26864 & 0,32886 & $-0,03454$ & 0,57555 & $-0,28389$ \\
\hline & Indonesian export growth & 0,25315 & 0,43892 & $-0,03128$ & 0,51103 & $-0,21819$ \\
\hline \multirow{2}{*}{ Palm oil } & Standard growth & 0,25285 & 0,13028 & 0,30155 & 0,20346 & $-0,07126$ \\
\hline & Indonesian export growth & 0,33945 & 0,26484 & 0,33706 & 0,20226 & $-0,03324$ \\
\hline
\end{tabular}

Indonesian export development got higher than the standard development which was only in the period of 2001 to 2003, 2004 to 2006 , and 2007 to 2009 . While for the palm kernel oil product, Indonesian export development got higher only in the period of 2001 to 2003 and 2004 to 2006 . This condition goes along with research of Hagi et al. (2012) that development of palm oil export in Indonesia was able to take the economy opportunity like the increasing of the trade development of palm oil in the world market for the period of 1995 to 2009.

The plantation product for the category of HS 4-dight code, the export development of coffee product in Indonesia was higher than the standard development which happened in the period of 2001 to 2009 and 2013 to 2015 . It was the same as the cocoa product that Indonesian export development was higher than the standard development which went on in the period of 2001 to 2009 and 2013 to 2015. While for the rubber product, Indonesian export development was higher than the standard development which only happened in the period of 2004 to 2009 and the period of 2013 to 2015. For palm oil products, Indonesian export product was higher than the standard development which occurs in the period of 2001 to 2009 and 2013 to 2015.

Based on Table 3, development of plantation product export in Indonesia experienced negative development during the period of 2001 to 2015 since the value was under the develoment of world export. This was suspected to be caused by (1) the composition of plantation products exported by Indonesia did not really follow the needs of world market which was reflected by the effect value of product composistion that had negative 
values; (2) the export of plantation product from Indonesia had not directed to the importing countries that had higher import development as seen by the effect value of market distribution with negative values; (3) the product competitiveness of Indonesian plantation in the world market was still weak shown by the effect of competitiveness with negative value; and (4) there was global economical crisis which influenced the large number of requests of plantation products from Indonesia in importing countries (Ermawati \& Saptia, 2013; Suprihatini, 2005). The negative development of export performance gave implication that the competitiveness of export products was the important thing that had to be studied by the exporting countries as one of the success keys in developing export products and increasing export performance in the free trade era right now. The exporting country cannot maintain and even develop more than the exporting countries that have higher product competitiveness. The increasing of competitiveness can be done by the development of technology innovation continuously by paying attentition to the principle of production efficiency and the increasing of product quality (Hadi \& Mardianto, 2004).

\section{Product Composition Effect}

On the aspect of composition products, it is seen that the composition effect of the product for each of the plantation commodities with HS 6-dgit code had negatively market value. However, the negative parameter of the product composition on each of the commodities occured in different year. Based on the analysis result of those five commodities in Table 4, it was known that the cocoa had negative effect value of product composition which occured in the period of 2004 to 2006 and 2010 to 2012 . This condition was suspected that there was the change of the demand from the world market so that Indonesia needs to strengthen the export segment with specific commodity in certain market of the country (Dermoredjo \& Setiyanto, 2008). According to Hasibuan et al., (2012), cocoa bean products from Indonesia was less responsive to the change of market demand so the quality of the beans needed to be increased by adjusting to the needs of cocoa products in the export destinations. Therefore, Indonesia needed market analysis to discover the quantity and the quality of export goods based on the market demand (Oktaviani et al,. 2008). Furthermore, the negative effect value of product composition on coffee beans happened during 2001 to 2003 and 2013 to 2015 . In natural rubber products, the negative product composition effect happended in the period of 2007 to 2009 and 2013 to 2015. While for the palm oil products, it had negative product composition value in the period of 2013 to 2015 and the palm kernel oil had the negative product composistion effecr in 2010 to 2015.

The negative effect reglected that the contribution of plantation commodity in Indonesia in form of primary products in international market was still low. This condition meant that Indonesia was still lack of attention of import development from the plantation commodity based on the product composition in international market. As stated by Hadi \& Mardianto (2004) that weak composition product was assumed to be caused by market intelligence of Indonesia was still weak. Indonesia did not really observed the offering change and the demand of plantation commodity product which moved dynamically in international market. This was related to the lack of Indonesian ability in responding to various chances of plantaion product export to importing county that had high import development. 
Table 4. Effects of product composition of Indonesian coffee, cocoa, rubber and palm oil (6-digits and 4-digits HS Code) in 2001-2015

\begin{tabular}{lrrrrr}
\hline \multirow{2}{*}{ Commodity } & \multicolumn{5}{c}{ Product composition effect } \\
\cline { 2 - 6 } & \multicolumn{5}{c}{ Year } \\
\cline { 2 - 6 } & $2001-2003$ & $2004-2006$ & $2007-2009$ & $2010-2012$ & $2013-2015$ \\
\cline { 2 - 6 } Coffee beans & $-0,00013722$ & 0,00034475 & 0,00046986 & 0,00037669 & $-0,00003994$ \\
Cacao beans & 0,00067467 & $-0,00044185$ & 0,00133301 & $-0,00076164$ & 0,00021639 \\
Natural rubber & 0,00001892 & 0,00000980 & $-0,00000442$ & 0,00001080 & $-0,00000836$ \\
Crude palm oil & 0,00180658 & 0,00093528 & 0,01043571 & 0,00185123 & $-0,00289091$ \\
Crude palm kernel oil & 0,00029526 & 0,00059175 & 0,00143465 & $-0,00032532$ & $-0,00007242$ \\
& & $H S 4-$ digits code & & \\
Coffee & $-0,00009343$ & 0,00035946 & 0,00055685 & 0,00032338 & 0,00007936 \\
Cocoa & 0,00062361 & $-0,00067462$ & 0,00095297 & $-0,00065447$ & 0,00044287 \\
Rubber & 0,00322720 & 0,00457111 & $-0,00274875$ & 0,01376650 & $-0,00947075$ \\
Palm oil & 0,00522571 & $-0,00233780$ & 0,01853831 & 0,00575699 & $-0,00399273$ \\
Source: processed secondary data. & & & & \\
\end{tabular}

In Table 4, it can be seen that palm oil was the commodity that had highest negative product composition effect and it was followed by palm kernel oil, cocoa beans, coffee beans and natural rubber. Even though its negative value was the highest, palm oil could have highest positive product composition effect. The positive value from the product composition effect indicated that the export contribution on the natural rubber could be increased by improving the product competitiveness and increasing the additional value of the product. As it is seen from Table 4 that the composition effect value of rubber product (HS 4-digit code) gets higher if its is classified into derivative product category from the rubber.

While for the group of product with HS 4-digit code shows that the product composition effect from each commodity having negative values in different period. This means that Indonesia has not exported the coffee, cocoa, rubber and palm product which are based on the development of world demand. Besides, the negative value was also caused by decreasing of world demands towards the group of plantation products that is caused by decreasing of world demand on the plantation product group as the consequence of global economy crisis which slow down the economical development in importing countries. This condition becomes a challenge as well as an opportunity for Indonesia to increase the rate of export development from the plantation products with product competitiveness that is the same as the demand from world market. Therefore, one of the efforts which can be taken to increase the rate is by increasing the export contribution in the plantation products in form of downstream products. This effort should be supported by policy of government which has condusive relation with the development of downstream industries.

\section{Market Distribution Effect}

Observed from the distribution of the market, the distribution effect of plantation commodity market in form of primary products (HS 6-digit code) in ASEAN market showed the negative tendency especially for cocoa beans and natural rubber. The effect of market distribution for palm oil was only negative in 2013 while the product of plam kernel oil had negative effet of market distribution in 2012 and 2013. For natural rubber, the negative effect of market distribution happened in 2011, 2013, and 2015. On cocoa beans, the negative effect of market distribution occurred in 2011, 2012, and 
2015 while the negative effect of market distribution for coffee beans took place in 2014.

The negative effect on market distribution effect indicated that the product distribution of Indonesian plantation commodities in form of primary products to ASEAN regions did not really pay attention to the importing development in ASEAN regions. The products of Indonesian plantation had not distributed well in the ASEAN regions especially cocoa beans and natural rubber. This is assumed due to the fact that those two products had not high competitivenss than the other exporting countries, such as Malaysia and Thailand. The weak competitiveness of the products caused Indonesia lost in competition with Malaysia and Thailand which also exported the same products. Hasibuan et al. (2012) mentioned that the ability of cocoa beans from Indonesia in ASEAN market was not responsive enough in facing the change of market demand especially from quality side. The distribution effect from natural rubber market from Indonesia showed that the negative value was due to the the increasing of competitors that enter the exporting market of Indonesia such as Vietnam and Liberia (Syahputra et al., 2014).

While for coffee bean product, crude palm oil or palm kernel oil, the distribution effect of Indonesian market to the ASEAN regions showed the positive tendency. This indicated that Indonesia had distributed the coffee beans, crude palm oil, and crude palm kernel oil to the countries in ASEAN area that had quite high import development. The commodity export was distributed well to traditional market or to the new markets which were in ASEAN areas. However, it has to be observed that Indonesia has competitors to take over the market segment of export in ASEAN areas, that are Malaysia for cocoa and palm oil products, Thailand for rubber and Vietnam for coffee.
On the other side, the distribution effect of the market for plantation primary product in European market from 2010 to 2015 indicated the positive tendency except for coffee, natural rubber and palm oil. The value of market distriburion effect for coffee in European market tended to have negative mark. This reflected that the coffee product from Indonesia had not distributed well yet to the countries considered coffee consumer in European areas. The low market distribution effect was because the coffee consuming countries in European areas expected certified coffee products. The coffee consumers in European regions have increasing demand and expectation relating to the health and food security issues in the coffee production process. Various demands and consumer expectation towards the coffee indirectly exposed for the certification scheme in coffee chain (ITC, 2011). Therefore, Indonesia needs to increase the quality of coffee products based on the consumer demand in European countries. At the same time, the negative value of palm product was due to the segment power of European Union and other countries which were still dominated by Malaysia (Susila, 2006). The effect of market distribution of natural rubber was negative which indicated that there were competitors such as Thailand that leaded the export segment in European markets.

Cocoa and palm oil had been well distributed to importing countries in European areas that had quite high market development. This showed that the Indonesian contribution in fulfilling the market in European areas was quite high especially for cocoa, natural rubber, palm oil and palm kernel oil. The effect of market distribution for product with HS 6-digit code is presented in Table 5.

The plantation product with HS 4-digit code showed that the effect of market distribution in ASEAN market tended to be negative. The negative effect value of market distribution 
Table 5. Effects of market distribution of Indonesian coffee, cocoa, rubber and palm oil (6-digits and 4-digits HS Code) in 2010-2015 in ASEAN and Europe markets

\begin{tabular}{|c|c|c|c|c|c|c|c|}
\hline \multirow{3}{*}{ Market } & \multirow{3}{*}{ Comodity } & \multicolumn{6}{|c|}{ Market distribution effect } \\
\hline & & \multicolumn{6}{|c|}{ Tahun } \\
\hline & & 2010 & 2011 & 2012 & 2013 & 2014 & 2015 \\
\hline \multicolumn{8}{|c|}{ HS 6-digits code } \\
\hline \multirow{5}{*}{ ASEAN } & Coffee beans & NA & 0,00009958 & 0,00014257 & 0,00006122 & $-0,00014128$ & 0,00000510 \\
\hline & Cocoa beans & NA & $-0,00077207$ & $-0,00051804$ & 0,00016493 & 0,00055409 & $-0,00026100$ \\
\hline & Natural rubber & NA & $-0,00000844$ & 0,00000847 & $-0,00000014$ & 0,00000046 & $-0,00000066$ \\
\hline & Crude palm oil & NA & 0,00503636 & 0,00141788 & $-0,00037438$ & 0,00009907 & 0,00000072 \\
\hline & Crude palm kernel oil & NA & 0,00014646 & $-0,00038710$ & $-0,00030430$ & 0,00003902 & 0,00017946 \\
\hline \multirow{5}{*}{ Europe } & Coffee beans & $-0,00018616$ & $-0,00003969$ & $-0,00002088$ & 0,00001436 & $-0,00019384$ & 0,00006739 \\
\hline & Cocoa beans & 0,00001794 & 0,00000275 & $-0,00000581$ & 0,00000284 & $-0,00000069$ & $-0,00000013$ \\
\hline & Natural rubber & $-0,00000009$ & $-0,00000092$ & 0,00000040 & 0,00000122 & $-0,00000022$ & $-0,00000182$ \\
\hline & Crude palm oil & $-0,00016938$ & $-0,00169609$ & 0,00228416 & 0,00223873 & $-0,00157297$ & $-0,00049712$ \\
\hline & Crude palm kernel oil & $-0,00110778$ & 0,00154816 & 0,00000684 & 0,00023148 & 0,00003379 & $-0,00003702$ \\
\hline \multicolumn{8}{|c|}{ HS 4-digits code } \\
\hline \multirow{5}{*}{ ASEAN } & Coffee & NA & 0,00008422 & 0,00012087 & 0,00002319 & $-0,00011337$ & 0,00001668 \\
\hline & Cocoa & NA & $-0,00009006$ & $-0,00025326$ & $-0,00011286$ & 0,00053354 & $-0,00020917$ \\
\hline & Rubber & NA & $-0,00147395$ & 0,00049118 & 0,00025364 & 0,00004566 & $-0,00002724$ \\
\hline & Palm oil & NA & 0,00640109 & $-0,00049813$ & $-0,00524701$ & $-0,00023297$ & 0,00204951 \\
\hline & Coffee & $-0,00015072$ & $-0,00004535$ & $-0,00000763$ & 0,00004962 & $-0,00010314$ & 0,00002752 \\
\hline \multirow{3}{*}{ Europe } & Cocoa & 0,00011228 & 0,00000304 & $-0,00015736$ & 0,00024677 & $-0,00007334$ & $-0,00014894$ \\
\hline & Rubber & 0,00066278 & $-0,00048480$ & $-0,00137993$ & 0,00071465 & 0,00075274 & $-0,00016132$ \\
\hline & Palm oil & $-0,00316117$ & $-0,00149086$ & 0,00154030 & 0,00264358 & $-0,00205298$ & 0,00022680 \\
\hline
\end{tabular}

Source: Processed secondary data; NA (not available).

for coffee took place in 2014 while the negative effect value of market distribution for cocoa happened in 2011, 2012, 2013, and 2015. The negative effect value of market distribution for rubber occured in 2011 and 2015 , while the negative effect value of market distribution for palm oil happened in 2011 and 2015. Even though the negative effect value of market distribution took place every year, the value effect of market distribution during 2011 to 2015 was on cocoa and palm oil (primary products and derivative). This indicated that those two products were not really distributed well to the importing countries that had high import development. This situation enables the countries in ASEAN areas to absorb a little of cocoa and palm oil from Indonesia. The weak effect value of market distribution of cocoa and palm oil of Indonesia in ASEAN markets was because Malaysia as the competitior had the excellence in the quality of cocoa and palm oil than Indonesia (Hagi et al., 2012; Hasibuan et al., 2012).
On the other side, the positive effect of market distribution in the period of 2011 to 2015 was on coffee and rubber. This indicated that the products were distributed well to the import destinations in ASEAN areas with quite high market development. In this case, Indonesia needs to pay attention to the offering change dynamics and demand in ASEAN market so they can choose the export destinations with quite high demand growth. The research result of Hadi \& Mardianto (2004) revealed that the negative development from market distribution effect in ASEAN markets especially agriculture products is caused by the innovation of relatively stagnant export product which causes on the little market segment of export product from Indonesia. It can be said that the export product of Indonesian agriculture is only distributed to certain export destinations in ASEAN areas. Therefore, Indonesia can do the expansion from one market to other potential markets that handle market overfull in ASEAN markets. 
In general, the market distribution effect for plantation products (coffee, cocoa, rubber, palm oil) in 2010 to 2015 tended to have negative value. This negative value occured because the downstream products from those three commodities couldnot really compete with the same products from other exporting countries. It was concerning that European markets determined tight standard of import products which had to be fulfilled by the exporting countries. As an example, implementation of international product certification for every product to be imported to the consumers in European areas. The European markets expected the inclusion of heavy metals content in the classification of the quality of export products. Negative issue about the forest damage and global warming was also suspected to weaken product competitiveness from Indonesia (Hagi et al., 2012). Furthermore, European markets included the countries with intermediate product producers from plantation products (coffee, cocoa, rubber, palm oil) so Indonesia needs to adjust to the requirement of product quality exported to the European areas. The negative value of market distribution effect also gives meaning that the plantation product of Indonesia has not distributed well yet to the traditional markets and new markets in European areas.

\section{Competitiveness effect}

Other parameter measured in the analysis of Constant Market Share is the competitiveness effect. The analysis result for the product with HS 6-digit code shows that the effect of competitiveness in ASEAN market during 2011 to 2015 tended to have negative value except for coffee beans The average value of competitiveness effect for each commodity in the period of 2011 to 2015 was 0,00007465 for coffee beans, $-0,00072799$ for cocoa beans, $-0,00000202$ for natural rubber, $-0,00224180$ for palm oil and $-0,00014146$ for palm kernel oil. Based on the analaysis result, it is known that in general the coffee product in ASEAN markets have strong competitiveness than cocoa, natural rubber, palm oil and palm kernel oil. For primary products, the Indonesian coffee had stronger competitiveness than the competitors, so Indonesia can maintain and develop the market segment of coffee to the export destinations in ASEAN areas. The strong competitiveness of coffee is a form of economy actor attempt especially farmers to improve the quality and to increase the coffee production capacity. Futhermore, Indonesian coffee is also widely known by the coffee consumers. It is concerning that the demand dynamics of coffee in ASEAN areas increased. However, Indonesia must increase the quantity, quality, and continuity of coffee products because there is coffee producers that become potential competitors for Indonesia which is Vietnam.

At the same time, cocoa, natural rubber, palm oil and palm kernel oil still had weaker position than the other competitors in ASEAN areas. The competitors are Malaysia and Thailand that include export country for cocoa, rubber and palm oil commodities with strong product competitiveness. The weak competitiveness of the three commodities is reflected from the negative competitiveness. The implication from the weak competitiveness is that Indonesia has to increase and improve the product competitiveness especially from the quality side by adjusting to the demand of the market.

In European markets, the effect of competitiveness during 2010 to 2015 which was positive was natural rubber while the competitiveness of coffee, cocoa, palm and palm kernel oil was negative. The average value of competitiveness effect on each commodity in European market from 2010 to 2014 was $-0,00015987$ for coffee beans, $-0,00002577$ 
for cocoa beans, 0,00000182 for natural rubber, $-0,00066379$ for palm oil and $-0,00017222$ for palm kernel oil. Based on the five primary products, the commodity with strong competitiveness in European market was natural rubber while the other commodity still had weak competitiveness in the market. This condition indicates that Indonesia is still lost in competition with the other exporting countries with the same products that enters European markets. As mentioned before, there was a tight competition in entering the European markets concerning the demands and the expectation of consumers in the countries that keep developed. Therefore, Indonesia must produce primary plantation products (coffee, cocoa, natural rubber, palm oil, palm kernel oil) which have high competitiveness in entering European areas. The development of competitiveness effect for coffee, cocoa, natural rubber, palm oil, and palm kernel oil from Indonesia in ASEAN and European markets in 2010 to 2015 can be seen in Table 6 .

The analysis result for products with HS 4-digit code show the same result as the product analysis with HS 6-digit code products. The competitiveness effect in ASEAN markets during 2011 to 2015 tended to have negative value except for the competitiveness of coffee. The average value of competitiveness effect for each commodity in 2011 to 2015 was 0,00007831 for coffee group, $-0,00064398$ for cocoa group, $-0,00040981$ for rubber group, and $-0,00130866$ for palm oil group. In general, the coffee group from Indonesia in ASEAN markets have relatively strong competitiveness than the other group product like cocoa, rubber, and palm. It can be said that the Indonesian coffee either as primary products or the downstream one, has the stronger competitiveness than the other exporting countries that become Indonesian competititors. One of the excellences of Indonesian's coffee is that Indonesia is able to produce special coffee with unique taste loved by foreigners.

The competitiveness effect of plantation products in European countries during 2010 to 2015 that had positive value were cocoa rubber and palm oil while the coffee had negative value. The average value of competitiveness effect on each commodity in European markets during 2010 to 2015 was $-0,00018327$ for coffee product, 0,00010370 for cocoa product, 0,00031042 for rubber, and 0,00006768 for palm group. The cocoa, rubber and palm in general had quite strong competitiveness in European areas reflected from the effect of competitiveness with positive value during 2010 to 2015. This indicates that the demand of primary products and the derivative products of cocoa, rubber, and palm oil from Indonesia in European markets is quite high. Futhermore, those commodities can compete with other exporting countries in defending the market segment in European markets. In 2010 to 2015 , only coffee commodity that had weak competitiveness in European markets. The weak competitiveness of Indonesian coffee was suspected that the consumers in Europe applied the tight standardization product on import products that enter to the country. The quality standard of the product is related to the issues of food security, health, social and environmental preservation, but some aspects related to the trade policy applied by the consumers in European countries that need to be paid attention to.

The effect of competitiveness development for coffee, cocoa, rubber and palm oil from Indonesia in ASEAN and European markets from 2010 to 2015 is presented in Table 6 . The weak competitiveness of some Indonesian plantation products in ASEAN and European markets can be caused by the price and non-price factors because the measure of competitiveness uses CMS method that is related to those factors. Therefore, Indonesia 
Table 6. Effects of competitiveness of Indonesian coffee, cocoa, rubber and palm oil (6-digits and 4-digits HS Code) in 20102015 in ASEAN and Europe markets

\begin{tabular}{|c|c|c|c|c|c|c|c|}
\hline \multirow{3}{*}{ Market } & \multirow{3}{*}{ Commodity } & \multicolumn{6}{|c|}{ Competitive effect } \\
\hline & & \multicolumn{6}{|c|}{ Year } \\
\hline & & 2010 & 2011 & 2012 & 2013 & 2014 & 2015 \\
\hline \multicolumn{8}{|c|}{ HS 6-digits code } \\
\hline \multirow{5}{*}{ ASEAN } & Coffee beans & NA & $-0,00012664$ & 0,00013972 & 0,00031657 & $-0,00036344$ & 0,00040705 \\
\hline & Cocoa beans & NA & $-0,00116815$ & $-0,00056585$ & 0,00049557 & $-0,00226700$ & $-0,00013454$ \\
\hline & Natural rubber & NA & $-0,00000356$ & $-0,00001866$ & 0,00000253 & 0,00000313 & 0,00000643 \\
\hline & Crude palm oil & NA & $-0,00589657$ & $-0,00495326$ & $-0,00134859$ & 0,00019184 & 0,00079759 \\
\hline & Crude palm kernel oil & NA & $-0,00061244$ & $-0,00034592$ & $-0,00014416$ & 0,00010688 & 0,00028836 \\
\hline \multirow{5}{*}{ Europe } & Coffee beans & $-0,00076364$ & $-0,00094699$ & 0,00054228 & 0,00060131 & $-0,00068428$ & 0,00029210 \\
\hline & Cocoa beans & 0,00021832 & $-0,00038407$ & 0,00000461 & $-0,00001049$ & 0,00000775 & 0,00000927 \\
\hline & Natural rubber & 0,00001634 & $-0,00000475$ & 0,00000001 & $-0,00000544$ & 0,00000447 & 0,00000027 \\
\hline & Crude palm oil & $-0,00042439$ & $-0,00348233$ & $-0,00037219$ & $-0,00020109$ & $-0,00041202$ & 0,00090926 \\
\hline & Crude palm kernel oil & 0,00074437 & $-0,00120119$ & $-0,00029112$ & $-0,00034755$ & 0,00019411 & $-0,00013193$ \\
\hline \multicolumn{8}{|c|}{ HS 4-digits code } \\
\hline \multirow{5}{*}{ ASEAN } & Coffee & NA & $-0,00010363$ & 0,00016494 & 0,00031512 & $-0,00036393$ & 0,00037907 \\
\hline & Cocoa & NA & $-0,00138002$ & $-0,00080095$ & 0,00076236 & $-0,00195986$ & 0,00015856 \\
\hline & Rubber & NA & $-0,00009073$ & $-0,00138136$ & $-0,00066352$ & $-0,00002700$ & 0,00011356 \\
\hline & Palm oil & NA & $-0,00725162$ & $-0,00059820$ & $-0,00041918$ & 0,00161109 & 0,00011463 \\
\hline & Coffee & $-0,00071210$ & $-0,00090481$ & 0,00048317 & 0,00041706 & $-0,00070715$ & 0,00032424 \\
\hline \multirow{3}{*}{ Europe } & Cocoa & 0,00017225 & $-0,00009697$ & 0,00000413 & $-0,00015655$ & 0,00053562 & 0,00016374 \\
\hline & Rubber & 0,00173667 & 0,00035743 & $-0,00075741$ & 0,00060297 & $-0,00025439$ & 0,00017727 \\
\hline & Palm oil & 0,00158715 & $-0,00287622$ & 0,00008346 & 0,00044165 & 0,00245725 & $-0,00128719$ \\
\hline
\end{tabular}

Source: processed secondary data.

needs to try to increase the competitiveness either from price, fluctuation of currency, quality, time, and export activity services, and product certification to the export destinations becoming the targets (Athanasoglou et al., 2010).

\section{CONCLUSION}

Comparative excellence of coffee, cocoa, rubber and palm oil during 2001-2015 had decreasing tendency with the highest competitiveness was on palm oil (73.0608 for palm kernel oil and 44.329 for palm and the derivative). Export development from Indonesian for the entire total of coffee, cocoa, rubber and palm in 2001 to 2015 was still higher than the standard development. The composition effect of coffee, cocoa, rubber and palm oil in 2001 to 2015 tended to have positive parameter so it followed market need. Market distribution effect of primary products in European markets was better than ASEAN markets during the period of
2011 to 2015 with more positive parameter values. The market distribution effect with HS 4-digit code in ASEAN markets was better than the European one in 2010 to 2015 with more positive parameter. Competitiveness effect of strong primary products was indicated by green coffee products in the ASEAN markets and natural rubber products in the European markets. Meanwhile, the products with 4-digits HS codes that had the effect of strong competitiveness was coffee products in ASEAN markets and cocoa, rubber and palm oil in European markets. Indonesian export growth dynamics were generally more affected by the influence of export growth and composition of the product compared with the distribution of securities markets and competitiveness.

\section{REFERENCES}

Arifin, B. (2013). On the competitiveness and sustainability of the Indonesian agricultural export commodities. ASEAN 
Journal of Economics, Management and Accounting, 1, 81-100.

Arip, M.A.; L.S. Yee \& T.S. Feng (2013). Assessing the competitiveness of Malaysia and Indonesia palm oil related industry. World Review of Business Research, 3, 138-145.

Athanasoglou, P., C. Backinezos \& E. Georgiou (2010). Export Performance, Competitiveness and Commodity Composition. Munich Personal RePEc Archive (MPRA) Paper No. 31997. Athens, Greece.

Bustami, B.R. \& P. Hidayat (2013). Analisis daya saing produk ekspor Provinsi Sumatera Utara. Jurnal Ekonomi dan Keuangan, 1, 56-71.

Chor, D. \& M. Kalina (2012). Off the cliff and back? Credit conditions and international trade during the global financial crisis. Journal of International Economics, 87, 117-133.

Daryanto, A. (2009). Posisi daya saing pertanian Indonesia dan upaya peningkatannya. Seminar Nasional Peningkatan Daya Saing Agribisnis Berorientasi Kesejahteraan Petani, p. 1-32. Indonesia: Bogor.

Dermoredjo, S.K. \& A. Setiyanto (2008). Analisis perdagangan kakao Indonesia ke Spanyol. Seminar Nasional Dinamika Pembangunan Pertanian dan Pedesaan: Tantangan dan Peluang untuk Peningkatan Kesejahteraan Petani, p. 329-345. Indonesia: Bogor.

Ditjenbun (2014). Statistik Perkebunan Indonesia 2013-2015: Kopi. Direktorat Jenderal Perkebunan, Kementerian Pertanian. Jakarta.

Ditjenbun (2014). Statistik Perkebunan Indonesia 2013-2015: Kakao. Direktorat Jenderal Perkebunan, Kementerian Pertanian. Jakarta.

Ditjenbun (2014). Statistik Perkebunan Indonesia 2013-2015: Kelapa Sawit. Direktorat Jenderal Perkebunan, Kementerian Pertanian. Jakarta.
Ditjenbun (2014). Statistik Perkebunan Indonesia 2013-2015: Karet. Direktorat Jenderal Perkebunan, Kementerian Pertanian. Jakarta.

Dradjat, B.; A. Agustian \& A. Supriatna (2007). Ekspor dan daya saing kopi biji Indonesia di pasar internasional: Implikasi strategis bagi pengembangan kopi biji organik. Pelita Perkebunan, $23,159-179$.

Ermawati, T. \& Y. Saptia (2013). Kinerja ekspor minyak kelapa sawit Indonesia. Buletin Ilmiah Litbang Perdagangan, 7, 129-147.

Fidrmuc, J. \& I. Korhonen (2009). The Impact of The Gobal Financial Crisis on Business Cycles in Asian Emerging Economies. BOFIT Discussion Papers 11/2009. Helsinki, Finland.

Hadi, P. U. \& S. Mardianto (2004). Analisis komparasi daya saing produk ekspor pertanian antar negara ASEAN dalam era perdagangan bebas AFTA. Jurnal Agro Ekonomi, 22, 46-73.

Hadi, P.U. \& S. Friyatno (2008). Peranan sektor tembakau dan industri rokok dalam perekonomian Indonesia: Analisis Tabel I-O Tahun 2000. Jurnal Agro Ekonomi, 26, 90-121.

Hagi, S. Hadi \& E. Tety (2012). Analisis daya saing ekspor minyak sawit Indonesia dan Malaysia di pasar internasional. Jurnal Pendidikan Ekonomi \& Bisnis, 4, 180-191.

Hakim, N. (2003). Strategi pemasaran kopi dalam menghadapi over supply, isu ecolabelling dan isu ochratoxin. Warta Pusat Penelitian Kopi dan Kakao Indonesia, 19, 22-38.

Hasibuan, A.M.; R. Nurmalina \& A. Wahyudi (2012). Analisis kinerja dan daya saing perdagangan biji kakao dan produk kakao olahan Indonesia di pasar internasional. Buletin RISTRI, 2, 57-70.

ITC (2011). Trends in the Trade of Certified Coffees. International Trade Centre. Geneva, Switzerland. 
Mardiantony, T. \& U. Ciptomulyono (2012). Penerapan analisis Input Output dan ANP dalam penentuan prioritas pengembangan sub sektor industri di Jawa Timur. Jurnal Teknik ITS, 1, 455-459.

Nurlatifah, H. (2011). Analisis daya saing produk-produk Indonesia di pasar China. Jurnal Al-Azhar Indonesia Seri Pranata Sosial, 1, 1-10.

Nuryanti, S. (2008). Nilai strategis industri sawit. Analisis Kebijakan Pertanian, 6, 378-392.

Oktaviani, R.; Widyastutik \& T. Novianti (2008). Integrasi perdagangan dan dinamika ekspor Indonesia ke Timur Tengah (Studi kasus: Turki, Tunisia dan Maroko). Jurnal Agro Ekonomi, 26, 167-189.

Permatasari, I.G.A.I. \& S. D. Rustariyuni (2015). Analisis daya saing ekspor biji kakao Indonesia ke kawasan ASEAN periode 2003-2012. E-Jurnal Ekonomi Pembangunan Universitas Udayana, 4, 855-872.

Radityo, S.I.; R. Dwiastuti \& A.W. Muhaimin (2014). Daya saing karet alam Indonesia di pasar dunia. Habitat, XXV, 143-150.
Rifin, A. (2010). Export competitiveness of Indonesia's palm oil product. Trends in Agricultural Economics, 3, 1-18.

Simorangkir, I. \& J. Adamanti (2010). Peran stimulus fiskal dan pelonggaran moneter pada perekonomian Indonesia selama krisis finansial global: Dengan pendekatan Financial Computable General Equilibrium. Buletin Ekonomi Moneter dan Perbankan, 13, 169-192.

Suprihatini, R. (2005). Daya saing ekspor teh Indonesia di pasar teh dunia. Jurnal Agro Ekonomi, 23, 1-29.

Susila, W.R. (2006). Peluang pengembangan kelapa sawit di Indonesia: Perspektif jangka panjang 2025. SOCA (Socio-Economic of Agriculturre and Agribusiness), 6, $1-9$.

Syahputra, Y.R.; S. Tarumun \& J. Yusri (2014). Analisis daya saing ekspor karet alam (natural rubber) Indonesia di pasar internasional. Jurnal Online Mahasiswa Fakultas Pertanian Universitas Riau, $1,1-9$.

$$
* * 0 * *
$$

